\title{
Taxonomic Review of the Fungivorous Tenebrionid Boletoxenus Motschulsky, 1858 (Coleoptera: Tenebrionidae: Tenebrioninae: Bolitophagini) in Korea with Host Fungi
}

Boo Hee JUNG*

Department of Life Sciences, Yeungnam University, Gyeongsan-si, Korea

\section{한국산 균식성 거저리, 도깨비거저리속 [Boletoxenus Motschulsky]|[딱정벌리목: 거저리과: 거저리아과: 가시거저리족의 분류학적 검토와 숙주버섯}

정부희*

영남대학교

\begin{abstract}
The Korean Boletoxenus known as fungivorous are taxonomically reviewed as two species including a new recorded species, Boletoxenus incurvatus (Lewis, 1894). And the host fungus of B. incurvatus is revealed through this study. Therefore, we provide the taxonomical information as well as the ecological information on the host fungi of the Korean Boletoxenus species.
\end{abstract}

Key words: Boletoxenus bellicosus (Lewis), Boletoxenus incurvatus (Lewis), Boletoxenus, Fungivorous tenebrionid, Korea, Fungal host.

초 록: 버섯에서 서식하는 한국산 도깨비거저리속(Boletoxenus Motschulsky)을 미기록종 아기도깨비거저리[Boletoxenus incurvatus (Lewis)]를 포 함하여 총 2종으로 재검토하였다. 또한, 아기도깨비거저리의 숙주버섯을 처음으로 밝혀 보고하였다. 따라서 이번 연구에서는 한국산 도깨비거저리 속에 대한 분류학적 정보와 더불어 한국산 종들의 숙주버섯에 대한 생태적 정보를 제공하였다.

검색어: 아기도깨비거저리, 도깨비거저리, 도깨비거저리속, 균식성 거저리, 숙주버섯.

The fungivorous tenebrionid Boletoxenus Motschulsky is reported as 12 species in the world (Gebien, 1944) Among them, six species occur in the Oriental region and the Palearctic region (Löbl et al., 2008). Only four species are distributed throughout the northeast Asia (Korea and Japan) and Far East (Löbl et al. 2008). The genus can be identified by the following morphological features: antennae capitate, usually enlarged, depressed and slightly serrate from seventh antennomere to

*Comesponding author: starrylight12@hanmail.net

Received February 24 2012; Revised June 182012 Accepted July 22012 apex; apical antennomere embedded in apex of 10th antennomere; pronotum usually with a pair of horns in male and gibbose in female; lateral sides of pronotum broadly explanate and arcuate; apical part of 8th sternite distinctly emarginate; parameres of aedeagus extremely smaller than tegmen (Miyatake, 1964).

The members of Boletoxenus are known as mostly fungivorous (Chǔjô, 1992). Boletoxenus bellicosus were typically feeding and breeding in the fruiting bodies of lignicolous fungi of order Aphyllophorales, particularly Fomes, Fomitopsis and Ganoderma throughout their life lives (Hayashi, 1966; Miyatake, 1964; Chǔjô, 1992; Jung et al., 2007). Especially, Boletoxenus 
bellicosus from Korea overwintered as adults and larvae (Jung et al., 2007).

The purpose of this study is to review the Korean Boletoxenus taxonomically and to account for the relationship between these tenebrionids and their host fungi. For this study, the materials were collected from host fungi growing on dead or decaying trees and also reared in the laboratory. The detailed morphological characters are carefully examined under stereomicroscopy (MZ APO Leica, Switzerland) and captured by using digital camera (Nikon D200, Japan). And the host fungi were identified based on Breitenbach and Kränzlin (1986) and Lee (1988). Specimens for this study have been deposited in Jung's Insect Collection (Seoul, Korea).

\section{Taxonomic Accounts}

Subfamily Tenebrioninae Latreille, 1802 (거저리아과)

Tribe Bolitophagini Kirby, 1837 (가시거저리족)

Genus Boletoxenus Motschulsky, 1858: 63 (도깨비거저리속)

Type species: Boletoxenus gibber Motschulsky, 1858.

\section{Key to the species of Korean genus Boletoxenus}

1. Body size 7.0 9.0mm; lateral margins of pronotum slightly serrate; in male, horn on anterior margin of pronotum long and slightly incurved B. bellicosus

- Body size 4.6 5.6mm; lateral margins of pronotum strongly serrate; in male, horns on anterior margin of pronotum short and strongly incurved

B. incurvatus

Boletoxenus incurvatus (Lewis, 1894) 아기도깨비거 저리 (Figs. 1, 2, 3, 4, 5, 6, 13)

Atasthalus incurvatus Lewis, 1894: 386.

Bolitoxenus bellicosus var. incurvatus: Gebien, 1925: 436

Bolitonaeus Galloisis Pic, 1932: 3

Boletoxenus incurvatus: Miyatake, 1964: 76.

Description. Body length about 4.6-5.6 mm; body small, shortly oblong-oval, strongly convex dorsally, with tubercles and squamosity dorsally, blackish brown to grayish brown, antennae and legs blackish brown. Head rugosely punctate; anterior margin arched outward, roughly crenulate; frons with several tubercles; antennae slender and short, not reaching base of pronotum; antennomeres 7 to 10 enlarged apically, antennomeres 7 and 8 slightly serrate inward, antennomeres 9 and 10 distinctly transverse, and apical antennomere slightly embedded in apex of 10th antennomere; clypeus without distinct carina, but with irregular granules forming transverse row. Pronotum rough, with numerous tubercles and with a pair of short and strongly incurved horns, projecting anteriad and not beyond the head, with tufts of yellow hairs on their apex in male, while with a pair of large protuberance, without horns in female; lateral sides expanded and flattened, strongly arcuate and regularly serrated; prosternum strongly and medially keeled. Elytra short-elongate and robust; striae with irregular, rough, large and sparse punctures; interstices with longitudinal crest-like carinae and small nodules, interstices 3 with regular and highly marked longitudinal tubercles, and interstice 7 with large and distinct tubercles; lateral sides serrate. Tibiae carinate, with rough punctures; tarsi densely setose ventrally, 4 basal tarsomeres of fore and middle legs compressed, and almost equal in length. Apex of last abdominal sternite deeply depressed with long and stiff setae in male, slightly depressed in female.

Specimens examined. $5 \sigma^{x} \sigma^{x} 5$ 우 우 and 10 larvae, Mt. Odae, Jinbu-myeon, Pyeongchang-gun, Gangweon-do, 6 VI 2008, B.-H. Jung, ex Fomitopsis pinicola.

Korean Fungal Host. Fomitopsis pinicola (Fr.) Karst.

Distribution. Korea [new record] and Japan.

Remark. Both adults and larvae of $B$. incurvatus inhabits in the Fomitopsis pinicola throughout their lives.

Boletoxenus bellicosus (Lewis, 1894) 도깨비거저리 (Figs. 7, 8, 9, 10, 11, 12, 14 )

Atasthalus bellicosus Lewis, 1894: 386.

Boletoxenus bellicosus: Gebien, 1925: 429, 436; Chûjô and Lee, 1992: 35; 1993: 110; Kim, 1995: 405; Kim, 1996: 15; Kwon et al,: 162; Jung et al., 2007: 194; Löbl et al., 2008: 238.

Specimens examined. $10^{x} 1$ \& Gwangleung, Pocheon-gun, Gyeonggi-do, 10 XII 1986; 1 오 Suwon, 1 IX 1988; $20^{\top} 0^{\top} 2$ 우 ○ Gwangneung, Pocheon-gun, Gyeonggi-do, 10 V 2006, H.-C. Park, ex Fomes fomentarius; $100^{\top} \sigma^{\top} 12$ 우 우 and 30 larvae Gwangneung, Pocheon-gun, Gyeonggi-do, 10 X 2006, B.-H. Jung, ex Fomes fomentarius (adults and larvae) and 

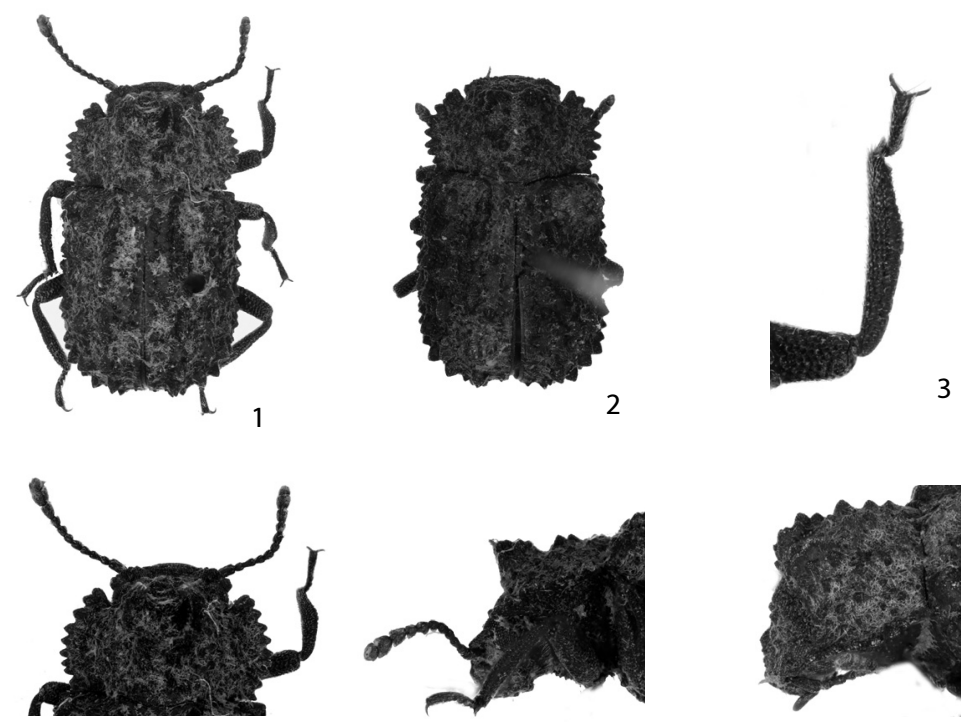

4

5

6

Figs. 1-6. Boletoxenus incurvatus. 1. male; 2. female; 3. male foreleg; 4. male head and pronotum (dorsal); 5 . male head and pronotum (lateral); 6. female head and pronotum (lateral).
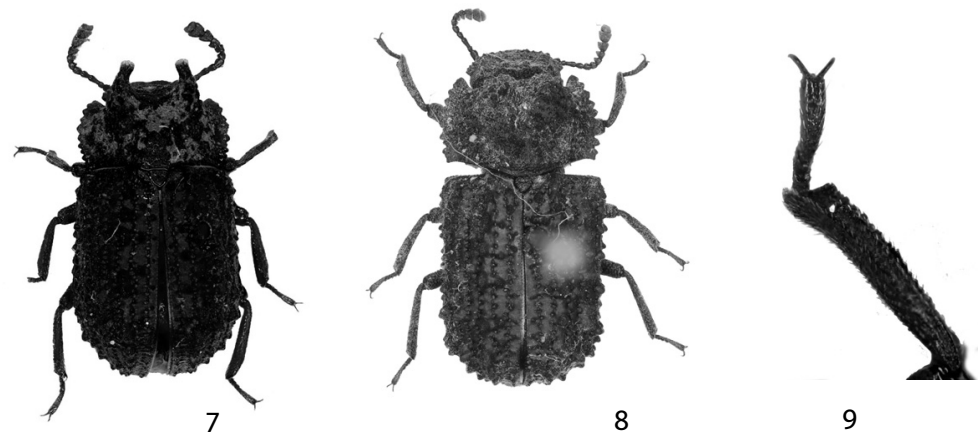

9

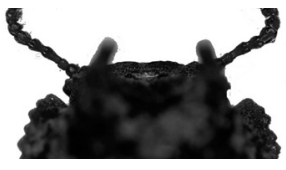

10

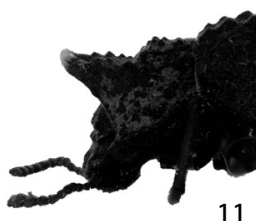

11

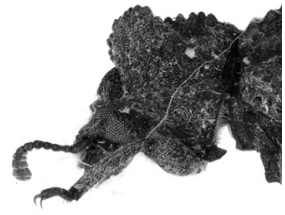

12

Figs. 7-12. Boletoxenus bellicosus. 7. male; 8. female; 9. male foreleg; 10. male head and pronotum (dorsal); 11. male head and pronotum (lateral); 12. female head and pronotum (lateral).

Perenniporia frazinea (1 우); $10^{\top} 2$ 우 우 Mt. Naejang, Jeongup-si, Jeollabuk-do, 11 X 2007, B.-H. Jung ex Perenniporia frazinea.

Distribution. Korea and Japan.

Korean Fungal Hosts. This species has been mostly observed feeding and breeding on the sporophores of Fomes fomentarius, rarely found feeding the sporophores of Perenniporia frazinea in Korea (Jung et al., 2007, Jung and Lee, 2011). Especially Fomes fomentarius is $50--200 \mathrm{~mm}$ in thickness and perennial (Breitenbach and Kränzlin, 1986; Lee, 1988) enough to make the chamber and inhabit in the fruiting bodies until completing their life cycle. During all life stage - larvae and adults, $B$. bellicosus fed from same host fungus individual." 

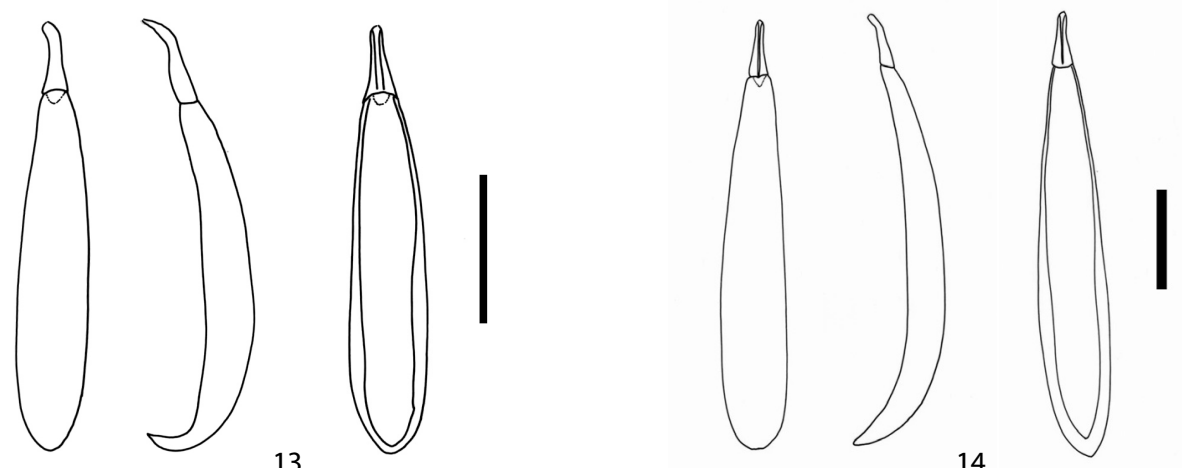

Figs. 13-14. Genitalia (Left: dorsal view; Middle: lateral view; Right: ventral view. Scale bar = 1mm). 13. Boletoxenus incurvatus, 14. Boletoxenus bellicosus.

Biological note. Most larvae passed through 4 instars, or rarely 5 instars. The body length of last instars averaged $11.0 \mathrm{~mm}$ $(\mathrm{n}=10)$, and the head width of last instars averaged $1.8 \mathrm{~mm}$ $(\mathrm{n}=10)$ respectively. The last instar is cylindrical in shape, white in color and weakly sclerotized on its surface except for mouthpart. And it is well-developed a pair of urogomphi in the ninth abdominal tergite. All larval stages burrowed inside the fungus and fed on the context and the hymenial layers. As instars developed, their chambers were filled with frass, and tunnels and chambers were built largely. The mating of the species mainly occurred at night, but, in some cases like as the shadowy surface and in the crevices of fruiting body in the laboratory, they often paired in daytime. B. bellicosus copulated for a few minutes in dark areas, posed climbing on the female's back. After mating, they deposited their eggs in fungal tissue, mostly on or into the pore of hymenium of the fruiting body one at a time. And also both the larval and adult stages overwintered in the fungal fruiting bodies.

\section{Acknowledgement}

This study was carried out through "The Survey of Korean Indigenous Species" supported by National Institute of Biological Resources (NIBR) of Ministry of Environment of Korea and also was supported by the National Research Foundation of Korea Grant funded by the Korean Government (Ministry of Education, Science and Technology) [NRF-2010355- C00092].

\section{Literature Cited}

Breitenbach, J. and F. Kränzlin. 1986. Fungi of Switzerland, Volume 2 - Non gilled fungi (Heterobasidiomycetes, Aphyllophorales, Gastromycetes). 412 pp. Verlag Mykologia, Switzerland.

Chŭjô, M.T. 1992. Fungivorous Tenebrionidae. Ins. Nat. 27(13): 9-14.

Chŭjô, M.T. and C.E. Lee. 1992. Tenebrionidae from Chejudo Island, Korea (Insecta, Coleoptera). ESAKIA 32: 31-46.

Chŭjô, M.T. and C.E. Lee. 1993. Korean Tenebrionidae (Insecta, Coleoptera). ESAKIA 33: 109-122.

Gebien, H. 1925. Die tenebrioniden des indomalayishcen gebietes, unter beruecksichtigung der bernachbarten faunen. II. Philip. J. Sci. 26(3): 423-445.

Gebien, H.1944. Katalog der Tenebrioniden. Teil III. Mitt. Mün. Entomo. Ges. 34: 842-899.

Hayashi, N. 1966. A contribution to the knowledge of the larvae of Tenebrionidae occurring in Japan (Coleoptera: Cucujoidea). Insect. Matsu. 1:1-41.

Jung, B.H., S.Y. Kim and J.I. Kim. 2007. Taxonomic review of the tribe Bolitophagini in Korea (Coleoptera: Tenebrionidae: Tenebrioninae). Entomol. Res. 37(3): 190-196.

Jung, B.H. and J.W. Lee. 2011. Fungal Hosts of Fungivorous Tenebrionid Beetles (Tenebrionidae) in Korea. Kor. J. Appl. Entomol. 50(3): 195-201.

Kim, W.T. 1995. Insect of Quelpart Island. Chejudo Folk National History Museum, Cheju. 614 pp.

Kim, J.I. 1996. The list of insects added 'Check list of insects from Korea (1994). Nat. Conserv. 93: 8-2.

Kwon, Y.J., J.H. Lee, D.J. Seo, S.L. Ahn, E.Y. Heo and Y.S. Yeo, 1996. Literature survey on biodiversity in Korea. Kor. Nat. Coun. Conser. Nat. pp. 504.

Kirby, W. 1837. The insects. In: Fauna boreali-Americana; or the zoology of the northern parts of British America: containing 
descriptions of the objects of natural history collected on the late northern land expeditions, under command of Captain Sir John Franklin, R.N. [Part 4.] ed by J. Richardson. J. Fletcher, Norwich. $x x x i x=325+[2]$ pp. 8 pls.

Latreille, P.A. 1802. Histoire Naturelle générale et particulière, des Crustacés et des insectes. Ouvrage faisant suite aux oeuvres de Leclerc de Buffon, et partie du cours complet d'histoire narurelle rédigé par C. S. Sonnini, membre de plusieurs sociétés savantes. Familles naturelles des genres. Tome troisième. F. Dufart, Paris. i-xii, 13-467 + [1] pp.

Lee, J.Y. 1988. Colored Korean Mushrooms (I). 365 pp. Academy, Seoul.

Lewis, G. 1894. On the Tenebrionidae of Japan. Ann. Mag. Nat. Hist. (6)13: 377-484, 4figs.
Löbl, I., O. Merkl, K. Ando, P. Bouchard, L.V. Egorov, D. Iwan, M. Lillig, K. Masumoto, M. Nabozhenko, V. Noväk, R. Petterson, W. Schawaller and F. Soldati. 2008. Family Tenebrionidae Latreille, 1802. pp. 105-352. In Catalogue of Palaearctic Coleoptera. Volume 5. Tenebrionoidea, eds. by I. Löbl \& A. Semetana. Apollo Books, Stenstrup, Denmark. 670 pp.

Miyatake, M. 1964. Notes on the tribe Bolitophagini of Japan, with the descriptions of four new genera and two new species (Coleoptera: Tenebrionidae). Trans. Shikoku Ent. Soc. 8(2): 59-84.

Motschulsky, V. de. 1858 Insectes des Indes orientales. 1: ière Série. Études Entomologiques 7: 20-122, 1 pl.

Pic, M. 1932. Diagnoses préliminaires. Mélanges Exotico-Entomologiques 59: 1-9. 